\title{
The Royal Bank of Scotland and Its Reputational Decline: A Case Study
}

\author{
Saud Al Taj \\ Lecturer of Human Resource Management, Glasgow Caledonian University \\ 40-48 Fashion Street, Spitalfields, London, E1 6PX, England \\ Tel: 44-750-102-9340Ｅ-mail: SaudAl.Taj@gcu.ac.uk
}

Received: July 7, 2015 Accepted: July 24, 2015 Published: August 7, 2015

doi:10.5296/bmh.v3i2.7974ＵRL: http://dx.doi.org/10.5296/bmh.v3i2.7974

\begin{abstract}
After decades of success in the global banking industry, the Royal Bank of Scotland fell to the brink of its collapse in 2008 owing to the recent global financial crisis that entirely shook the financial sector of the United Kingdom. The man whose leadership was once acknowledged for the remarkable success of the bank, former CEO Sir Fred Goodwin, was held entirely responsible for the collapse owing to his decisions of hostile acquisition of the ABN-Amro bank and pushing the banking industry into 'filthy' executive pay and bonus culture. The case study will review the evidence from 2000-2009 to discuss the rise and fall of the royal bank in the light of the corporate governance failures during the difficult times of global recession.
\end{abstract}

Keywords: reputation, financial crisis, recession, acquisition, corporate governance 


\section{Introduction and Background}

The Royal Bank of Scotland Group (RBSG) is a leading financial services group of Europe and owns a good reputation for successful and profitable acquisitions and integrations. The history of Royal Bank of Scotland (RBS) goes back to more than two centuries when it was founded in 1727 in Edinburgh, Scotland. The bank formed to break the monopoly of Bank of Scotland, which was the only operating bank of the country at the time. Ever since the royal bank was formed, significant growth, both organically and via acquisitions, has been observed. This royal bank merged with National Commercial Bank of Scotland in 1969 to become the largest Scottish bank with 700 branches and a 40 percent market share (Nohria \& Weber, 2005). Its first branch in London was opened in 1874 and thereafter built significant presence in England and Wales by 1920s through a series of acquisitions (Nohria \& Weber, 2005).

RBS started to grow rapidly since the later years of 1990s and eventually became one of the largest banks in the world. In terms of market capitalization it was the fifth largest bank (Nohria \& Weber, 2005). Alone in the United Kingdom (UK), the bank had 15 million customers and 2,200 branches (Kennedy et al., 2006). This was the result of some major initiatives that the bank took for the enhancement of its performance, but a major change took place when RBS went on to acquire a much bigger bank, NatWest (National Westminster Bank) in March 2000. NatWest had poor performance at the time of RBS acquisition so its successful integration posed a big challenge. This successful integration was eventually announced in February 2003 and was widely applauded by the financial community. Sir Fred Goodwin, the then Chief Executive of the bank, was named the Global Businessman of the Year by Forbes magazine for his achievements (Nohria \& Weber, 2005). He was also named the Best Bank CEO by Reuters. According to Goodwin, all these awards were recognition of the achievements of the entire organization rather than just himself (Nohria \& Weber, 2005).

The following section will discuss the rise and growth of the royal bank while shedding light on its successful acquisition of NatWest. We will further discuss how the 'star' bank rose to the glories of success under the dynamic leadership of CEO Sir Fred Goodwin. Later, we argue how the very same CEO was entirely held responsible for the collapse of the bank owing to the global recession and corporate governance failures. Finally, the situation of RBS following the recession is captured.

\section{Methodology: Systematic Literature Review}

This paper is based on the review of literature on the case of RBS and its reputational decline following the global financial recession and corporate governance crisis. Systematic literature review is a step-wise approach in which relevant keywords are determined and articles are included/excluded on criteria of relevance and quality by deploying specific methodology. The systematic review began with identifying relevant literature in the first stage by searching for the keywords in academic databases including: EBSCO, Blackwell Synergy, Emerald Fulltext, Elsevier Science Direct, and Google Scholar. The review included articles and papers published in academic journals and non-academic/professional reports and reputable newspapers between 1995 and 2009. This era was chosen so as to appropriately 
capture relevant details of the rise and fall of the royal bank and also to thoroughly examine the position of the bank at various time intervals including the time before and following the financial crisis of 2008. Different combinations of keywords were searched including: Royal Bank of Scotland, acquisition, global financial crisis, recession, corporate governance, leadership, economy, financial sector etc. As the search produced a large number of relevant articles and reports (approximately 460), they had to be condensed to ensure the inclusion of only relevant articles, reports and publications. Following the filtration process of reviewing the titles and abstracts of these publications, the final selection included a total of 56 articles/reports that were included in the full text review. Moreover, numerous books written on the subject area and the financial sector were also reviewed in the systematic process. Several newspapers and magazines (financial and non-financial) have also been consulted in the process.

\section{The Period of Growth}

RBS went into diversification in the 1980s and set up a car insurance company by the name of Direct Line. It entered the U.S. market later by acquiring Citizen's Financial Group and also formed a joint venture with Banco Santander in Europe. It launched online banking service in the UK, which was the first comprehensive on-line banking of the country. Joint financial services ventures were also formed with Tesco and Virgin Direct.

In the mid 1990s, Project Columbus was implemented by RBS which was its retail banking business's reengineering. Most back-office activities were shifted from paper-based to electronic. Increased revenues and efficiency were realized through this project which also enabled the bank to lower its cost-income ratio and enhance profitability. RBS also started to follow multi-brand strategy by operating different brands and selling similar products under different brands. The main man behind the show was Chief Executive Sir Fred Goodwin who was appointed in 1998 by Sir George Mathewson, the Chief Executive then, and put in line to succeed him as the Chief Executive in 2000.

\section{Successful Acquisition of NatWest}

The hostile acquisition of NatWest by RBS took place in February 2000. NatWest was a big bank of over three times the size of RBS. The bank was continuously losing competitive ground with its cost-income ratio increasing drastically (Kennedy et al., 2006). This acquisition deal, worth $£ 21$ billion, was the fourth largest transaction of the banking world and the largest acquisition of the UK banking history. By 2003, RBS had become one of the leading banks of the world with over 20 million customers in UK, £400 billion worth of assets, and 110,000 employees (Nohria \& Weber, 2005).

The bid for NatWest was not an easy game for RBS as it had to compete with its biggest rival, Bank of Scotland (BoS). However, both these banks were quite smaller than NatWest in size but better managed. A key to winning the NatWest bid by RBS was the demonstration of its ability of extracting major cost savings from the merged organization and also to improve income, along with the promise of delivery of a new force in banking and exploitation of international opportunities (Kennedy et al., 2006). The integration process served to be a 
major challenge for RBS as industry analysts were showing lack of faith in bank's abilities to successfully complete the integration process, they argued that firms usually underestimate the difficulties posed by integration of IT systems (Kennedy et al., 2006). This takeover was expected to improve the efficiency of the merged organization with lower costs of operations (synergies) and was expecting to achieve $£ 1.1$ billion reductions in cost by the end of three years (Kennedy et al., 2006).

Once the takeover was completed, the primary task of senior RBS managers was to understand the structure, systems, and operations of NatWest (Kennedy et al., 2006). These managers identified a total of 154 initiatives/projects that would accomplish the objectives. This would take around three years and would positively deliver the results via addressing the known inefficiencies of NatWest, merging the operating facilities of the two organizations, and through the application of best practices across the new organization (Kennedy et al., 2006). However, the fundamental opportunities included the following (Kennedy et al., 2006):

- $\quad$ Elimination of duplicated administrative centres

- $\quad$ Complementing operating processes

- $\quad$ Closing of NatWest data and moving them to RBS computer systems

After the activities and programmes of the integration were finalized, managers concentrated on their implementation. Team structures were developed with project staff that would work on each individual project and produce periodically reports indicating the results achieved, including programmes for control and progress reporting. The targets were broken down into monthly figures in order to periodically track the progress of the integration programme (Kennedy et al., 2006). This is how RBS had a successful integration process that exceeded board's expectations.

The bank was performing very well in the 1990s and had reduced its cost-income ratio from $56 \%$ to $52 \%$ between $1993-1998$. Its revenues grew by $16 \%$ and profits-before-tax shoot up by $31 \%$ (Nohria \& Weber, 2005). In 2003, RBS announced the successful completion of NatWest acquisition. The proud CEO Fred Goodwin was satisfied with the performance of his dynamic organization and the favourable aftermaths of this successful integration. The bank had increased its revenues, profits, and market capitalization. Moreover, the competitive position of RBS was also advanced. Its efficiency increased via reduced cost-income ratio and it had now become one of the dominant market players. Employees also felt proud of what they had achieved with their hard work and their morale had also increased as they were now part of a winning organization. On the other hand, customer satisfaction had also increased (Nohria \& Weber, 2005).

The acquisition integration capability of RBS had become world-class now and this was not only shown by the NatWest acquisition but also by the success in acquisitions by other units of RBS including the Direct Line and Citizens during this period. One of the major achievements during this time was the earning of the confidence of the market and trust of the customers which made it easy for this great bank to raise capital. It had now achieved the 
reputation of being the best bank for all its stakeholders including customers, employees, and shareholders. However, these successes were accompanied by questions for the future of RBS whether the bank will be able to sustain its position and reputation for long. Goodwin recognized the fact that few companies are actually able to sustain such positions for long but was confident that his bank would not only sustain the achieved market position and reputation but would also become a leading bank and one of the most admired organizations of the world.

The year 2005 proved to be a splendid one for the RBSG. At 31 ${ }^{\text {st }}$ December 2005, the group was in a tremendous position and possessed total assets of $£ 777$ billion, staff of 137,000 people and cost-income ratio of 42 percent (RBS Annual Report and Accounts, 2005). It was ranked 12 on the global high yield corporate bond league tables and 4 on global leveraged loan league tables. It has 2.7 percent share in the global high yield bond market and 5.4 percent share of leveraged loan market (Nohria \& Weber, 2005).

Yet a successful bank, in 2006 RBS had eight divisions facing customers. These included

- $\quad$ Royal Bank of Scotland Retail Banking

- $\quad$ NatWest Retail Banking

- Wealth Management

- $\quad$ Retail Direct

- $\quad$ Corporate Banking and Financial Markets

- $\quad$ RBS Insurance

- $\quad$ Ulster Bank Group

- $\quad$ Citizens (United States)

RBSG had a market capitalization of $£ 44.4$ billion as on $31^{\text {st }}$ December 2007. Also on this date, the group had total assets of $£ 1900.5$ billion and equity of $£ 53$ billion (Prospectus).

We now focus on the hostile acquisition of ABN-Amro, which actually led to the collapse of the royal bank and gave an opportunity to critics of Sir Fred Goodwin to raise fingers on him and his once acknowledged 'dynamic' leadership.

\section{The Hostile Acquisition of ABN-Amro}

In 2007, RBS competed with England's Barclays Bank over a bid to acquire the Dutch bank, ABN-Amro, which had presence in almost 53 countries. The royal bank was particularly interested in the Dutch bank due to its strength in the area of investment banking and that the acquisition would lead to lower synergy costs. Moreover, Fred Goodwin was also attracted towards the deal due to ABN's geographical diversity in emerging markets and via that RBS would have gained access to these markets (Euroweek, 2008). 
RBS was successful in winning the bid and acquired the Dutch giant for a price of \$106 billion in the month of October (Datamonitor, 2009). According to Sir Fred Goodwin, this price was very attractive for the ABN-Amro shareholders, whereas, financial analysts viewed this move of RBS as price aggressive and believed the bank has ended up over paying for the deal. However, the acquisition was perceived to be a smart move because ABN-Amro was a big bank and had international presence and was much stronger in the area of investment banking that could prove to be a good opportunity for RBS. Brian Stevenson, head of the new global transaction services division at RBS, seemed confident in April 2008 regarding the acquisition and stated that the merged organization will achieve success owing to the combination of the strong ABN-Amro platform plus RBS discipline (Lawrence, 2008).

RBS had gained confidence through the successful NatWest deal and expected the ABN acquisition to be as successful. However, the acquisition could not be saved from the negative effects of the credit crunch and it soon began to be believed that RBS had overpaid for the deal. Due to the worsening financial and economic conditions, RBS was pushed into $£ 12$ billion rights issue (Euroweek, 2008), which was the biggest in the world. This move, although generally considered to be correct, turned into a source of humiliation for CEO Fred Goodwin and the board and led to questions over the justification of the ABN-Amro deal. However, the general opinion of the deal is directly connected with the performance of the bank which has gone down due to the economic situation of the world and not much has been left within the hands of the RBS board as it has been almost $70 \%$ taken over by the government now. The rights issue took place as a result of sturdy amount of hybrid capital to finance the deal instead of new equity (Euroweek, 2008). However, the main cause of the rights issue was the write-downs of $£ 4.2$ billion on structured finance assets along with the understanding that conditions were becoming darker for global banks due to the credit crunch (Euroweek, 2008). Moreover, complications pertained in the process as it involved breaking apart ABN-Amro, which was difficult. Another problem was of slips in the timetables that invited unnecessary criticisms for the organization that had become a model of successful integration for others. Also, the indecisiveness over some key businesses invited criticism. Nevertheless, RBS and ABN businesses appeared in good shape and the acquisition lifted RBS in the European leagues tables according to Dealogic (Euroweek, 2008).

\section{Recession and Its Aftermaths: The Fall of RBS}

In the summer of 2007, negative signs of a recession were clearly visible via the credit crunch that had taken all the big economies of the world in its control. The crunch originated from the slash of the US mortgage markets and the effect had spread globally, including the UK. The country has faced several recessions in the last century, prior to the current economic crisis, averaging about 5 , which are regarded as the major ones. The twentieth century saw five major recessions in the UK of which the first two belonged to the interwar period and the rest occurred in 1973, 1979, and 1989 respectively. The worst being in 1929-1932 with a 13\% shortfall below trend in Gross Domestic Product (GDP) and exports falling by 40\% (Dow, 1999). The recent recession of 2008 was driven by the global financial crisis and was regarded "worse" than the Great Depression of 1930s. The UK economy was expected to grow by $2-2.5 \%$ in 2008 and $2.5-3 \%$ in 2009 and 2010 but unfortunately the growth in 2008 


\section{I Macrothink}

Business and Management Horizons

ISSN 2326-0297

2015, Vol. 3, No. 2

was less than $1 \%$ (UNISON, 2008). Also, in 2009, a GDP contraction of $2.6 \%$ was forecasted (Sentance, 2009), which indicated towards its poor performance.

After having splashing decades of success in the UK banking history and becoming one of the biggest banks of the world, RBS faced vertical downturn in the year 2008 and within no time reached the brink of collapse as a result of the economic recession in the country which was regarded as the worst recession in the last 70 years. The bank collapsed after having years of tremendous success with its massive acquisitions of nearly $\$ 90$ billion (Datamonitor, 2009) since 2000. It underwent an expensive and unprofitable acquisition of ABN-Amro along with high exposure to US sub-prime market (Datamonitor, 2009). The first ever loss of the bank in its 282 years of history was then signalled by the new CEO Stephen Hester. The following figure gives a glimpse of the situation existing in 2009 .

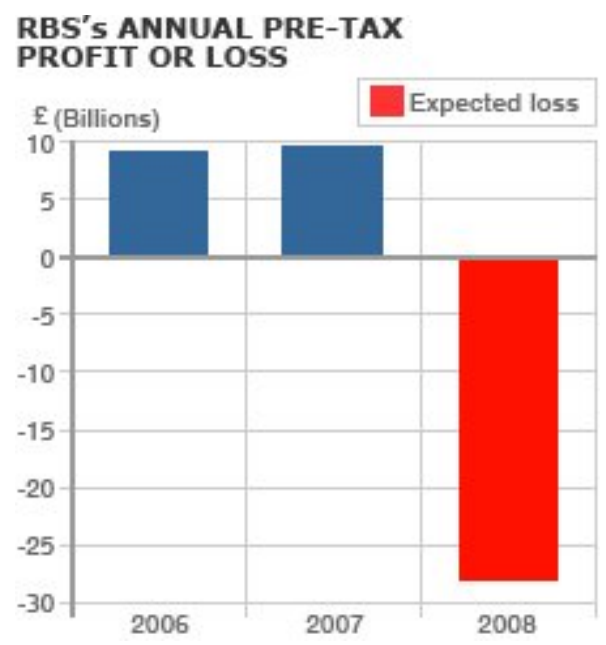

Figure 1. RBS share prices for 2004-09

Adapted from BBC News, 26 $6^{\text {th }}$ February, 2009

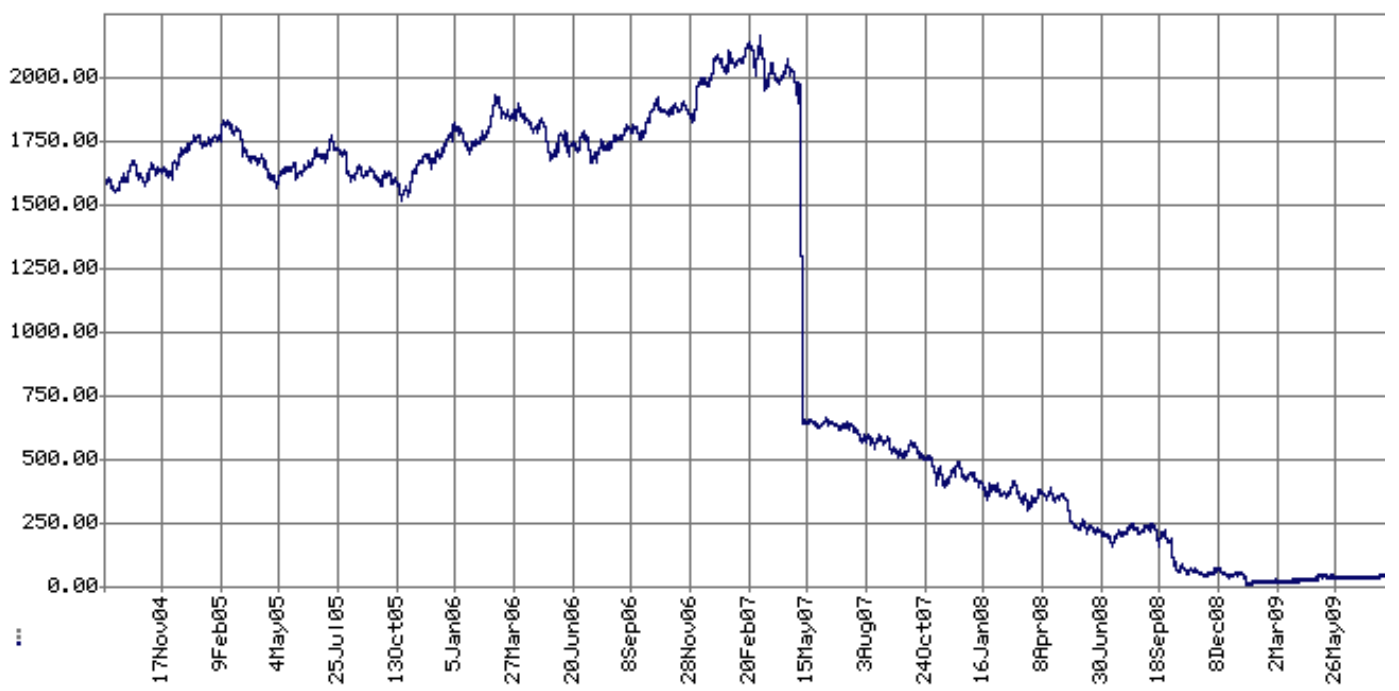




\section{Macrothink}

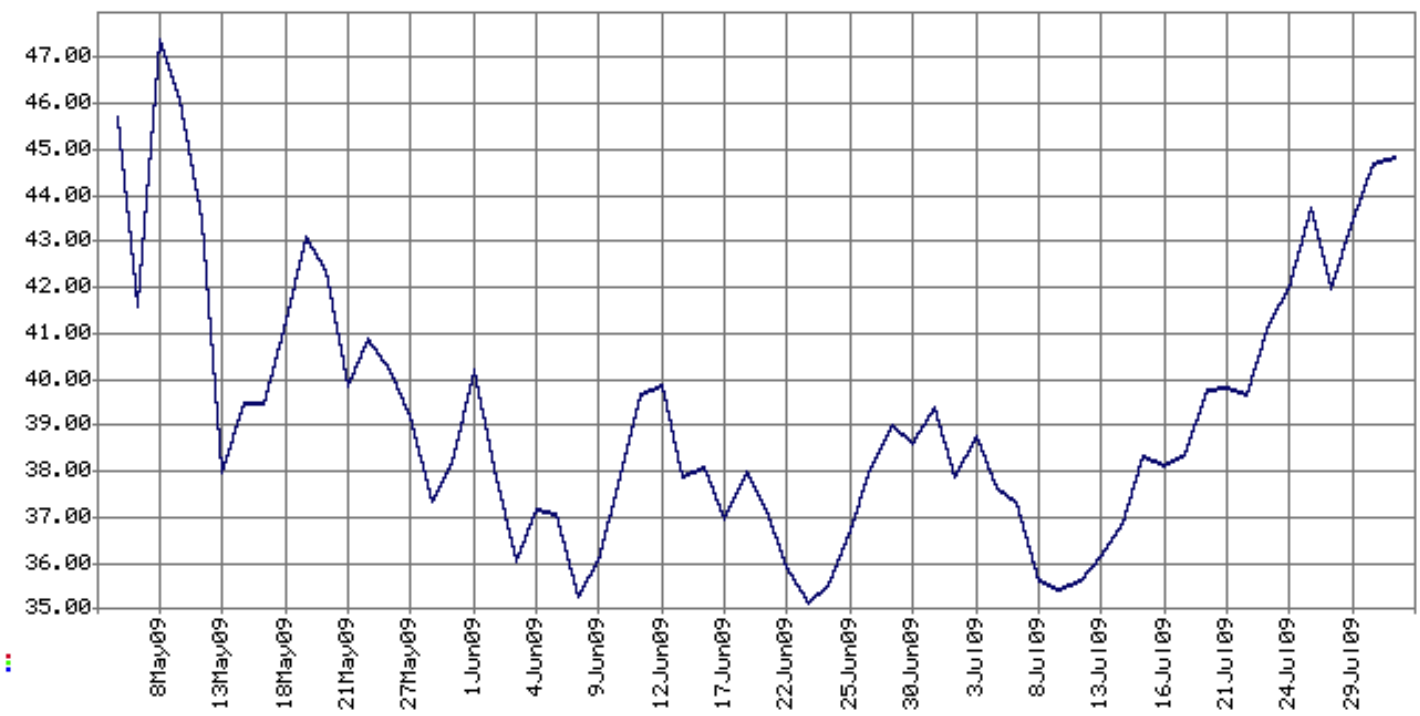

Figure 2. RBS share prices from May-Jul 2009

Source: www.lse.co.uk

RBS proved to be one of the biggest sufferers of the UK credit crunch in the later half of 2008 and underwent fatal crisis with record losses. In this difficult time, RBS faced huge challenges of bringing the bank out of the crisis and on the other hand keeping the staff motivated so that they work towards its revival. One of the major reasons for the financial crisis of the bank was considered to be the executives' bonus culture who were paid millions of pounds in bonuses and remunerations. The biggest blame of the crisis was put on CEO Sir Fred Goodwin, who had drawn millions over the years in bonus and remuneration payments for himself. He was eventually asked to leave the bank but by that time public opinion had turned negative against Sir Fred Goodwin and even after he left RBS, he remained a victim of public hatred and violence that went up to a stage where his personal home and car in Edinburgh were attacked by the members of the public (BBC News, 25 ${ }^{\text {th }}$ March 2009). On the other hand, Chancellor, Alistair Darling slashed the bonuses at RBS by 90 percent in accordance with its declaration that he wanted a change in culture of the banks (The Scotsman, 18 February, 2009).

RBS is now 70 percent owned by the public and therefore should be paying off absolute minimum amount of bonuses. The Chancellor further announced that there will be "no reward for failure" (The Scotsman, 18 February, 2009, p. 1). Despite this announcement, a rise of 10 percent was also announced as rise in pay of front-line staff. This included those earning less than $£ 19,000$. The bonus pool was cut from $£ 2.5$ billion to $£ 175$ million. The Edinburgh-based RBS also stated it would be paying only such guaranteed bonuses that were legally binding and would exclude any individual who contributed to the bank's massive losses would be missed out (The Scotsman, 18 February, 2009). 
RBS expected record losses of $£ 28$ billion by the end of February 2009 (The Scotsman, 18 February, 2009; BBC News, 26 ${ }^{\text {th }}$ February, 2009). On $10^{\text {th }}$ of February, 2009, the former Chief Executive and Chairman of RBS, Sir Fred Goodwin and Sir Tom McKillop, and former Chief Executive and Chairman of Halifax Bank of Scotland (HBOS), Andy Hornby and Lord Stevenson, were invited to the British Parliament at Westminster to be questioned by the parliamentary committee. The day turned out to be embarrassing for these former bosses who had to apologize to the parliamentarians and the public for their actions which led the two successful banks to their worse ever decline in recent years (The Scotsman, 11 February, 2009).

The meeting was followed by RBS announcement of cutting down jobs by 2 percent $(2,300$ out of a total 106,000 UK workforce) (The Herald, 11 February, 2009). Throughout the situation, former CEO Sir Fred Goodwin remained to be the key figure as he took home over $£ 5$ million in cash and shares in 2007 (Financial Times, 10 February, 2009). He recorded total earnings of $£ 22,502,000$ from 2000-2009, including $£ 13,295,000$ of bonus payments (The Scotsman, 10 February, 2009). After reaching the brink of its collapse in October 2008, the bank asked its CEO Sir Fred Goodwin to retire to avoid being sacked. The bank was then taken over by the UK government which intervened to survive the collapsing bank. Following retirement, his annual pension is $£ 703,000$ (BBC News, $3^{\text {rd }}$ March, 2009), which has been strongly criticized by the UK Financial Investments (UKFI) acting Chairman Glen Moreno who termed it as "reward for failure” (BBC News, $3^{\text {rd }}$ March, 2009).

Following the collapse and in an attempt to revive the ailing bank, the former government of Prime Minister Gordon Brown promised the bank $£ 25$ billion additional capital and also decided to spend an overall total of $£ 600$ billion towards the banking industry of UK (Wall Street Journal, $27^{\text {th }}$ February, 2009). Moreover, the ailing bank also decided to pullback from half of the 60 countries it was operating in and also to decrease its overall expenses by 10-15 percent (Wall Street Journal, 23 ${ }^{\text {rd }}$ February, 2009). According to the Bank Loan Report (2009), RBS planned to scale back their activities in structured real estate, leveraged and project finance, and also decided to exit any lending activities in these areas. It was also reported that due to the crisis in the bank, the total staff layoff from around the globe had reached 20,000 .

The losses reported by the bank in 2008 were the very first in the history of the bank, which is an indication of the amount of damage that was caused. However, the reasons behind the losses include the extra spending on acquisitions and takeovers by the bank as acquisitions of $\$ 90$ billion were reported since the year 2000 alone. Moreover, the expensive acquisition of ABN-Amro and exposure to the US sub-prime market through its Massachusetts based subsidiary, Citizens Bank had also left the bank in a shaky state. The losses of the US sub-prime laid significant impact on RBS due to its holding of toxic debts (Datamonitor, 2009). In a revival attempt, CEO Stephen Hester announced that the liquidity of the bank will be improved via the sale of assets so that the bank could pay off its $£ 20$ billion loan to the government. 


\section{Conclusion}

The Royal Bank of Scotland that once managed to keep its position in the top 5 banks of the world and was well known for its abilities and competencies of managing successful acquisitions, reached the brink of its collapse owing to the recent global financial crisis and recession in the UK economy along with the corporate governance failure due to the executive bonus culture that further added 'fuel to the fire'. Despite being exceptionally successful in its acquisition of the NatWest, the bank met failure in its attempt of hostile acquisition of ABN-Amro, which is considered to have occurred due to governance failure of its executives and their ability of pricing the deal fairly. Furthermore, the drawing of millions of pounds in executive bonuses is yet another form of corporate governance failure as it eventually led to the reputational decline of the bank as customers and employees lost trust in the bank. Therefore, in the light of the evidence presented in the case above, it can be concluded that the global financial crisis and the recession prevailing in the UK economy was not the only reason behind the collapse of RBS but the corporate governance failure in the form of poorly dealing with the acquisition deal and excessive executive pay and bonus culture were far much bigger reasons for the failure of a glorious bank.

\section{References}

Bank Loan Report. (2 ${ }^{\text {nd }}$ March, 2009). 24(9). Published by Source Media, Inc.

Conference Call. (2007). The Royal Bank of Scotland group plc acquisition of ABN Amro businesses. Fair Disclosure Wire (Quarterly Earnings Report), $16^{\text {th }}$ July.

Datamonitor. (2009). MarketWatch: global round-up. Feature Analysis. January, 139-140.

Dow, C. (1999). Analysing major recessions: an analytical summary of a new study of large recessions in the twentieth century. National Institute Economic Review, 167, 70-85. http://dx.doi.org/10.1177/002795019916700109

Euroweek. (18 ${ }^{\text {th }}$ July, 2008). RBS-ABN: even a perfect integration could be marred by credit crunch. 1063, p.56.

Kennedy, G., Boddy, D., \& Paton, R. (2006). Managing the aftermath: lessons from the Royal Bank of Scotland's acquisition of NatWest. European Management Journal, 24(5), 368-379. http://dx.doi.org/10.1016/j.emj.2006.04.001

Lawrence, N. (2008). How to make the most of a merger. Euromoney, 39, 119-122.

Mizen, P. (2008). The credit crunch of 2007-2008: a discussion of the background, market reactions, and policy responses. Federal Reserve Bank of St. Louis Review, 90(5), 531-567.

Munro, N. (1928). The history of the Royal Bank of Scotland 1727-1927. Edinburgh: R\&R Clark, Ltd.

Nohria, N., \& Weber, J. (2005). The Royal Bank of Scotland: masters of integration. Harvard Business Review, 9-404-026.

Prospectus The Royal Bank of Scotland Plc. 


\section{Macrothink}

Business and Management Horizons

ISSN 2326-0297 2015, Vol. 3, No. 2

RBS Annual Report and Accounts. (2005). [Online] Available: http://investors.rbs.com/ /media/Files/R/RBS-IR/Archived/fy-2005.pdf

Sentance, A. (2009). Monetary policy and the current recession. Institute of Economic Affairs' $26^{\text {th }}$ Annual State of the Economy Conference, 24 ${ }^{\text {th }}$ February (Speech).

UNISON. (October 2008). Public services and the credit crunch, Fact Sheet.

Wall Street Journal. (23 ${ }^{\text {rd }}$ February, 2009). 253(43), pC3.

Wall Street Journal. (27 ${ }^{\text {th }}$ February, 2009). 253(47), pA1-A12.

Weale, M. (2009). Data on the credit crunch. National Institute Economic Review, 207, 71-72. http://dx.doi.org/10.1177/0027950109103681

\section{Copyright Disclaimer}

Copyright for this article is retained by the author(s), with first publication rights granted to the journal.

This is an open-access article distributed under the terms and conditions of the Creative Commons Attribution license (http://creativecommons.org/licenses/by/3.0/). 